\title{
The Chinese perception of quality: model building and analysis based on consumers' perception
}

Hong Cheng, Dandan Li and Lianfa Luo*

\author{
* Correspondence: luo0708sky@163.com \\ Institute of Quality Development \\ Strategy, Wuhan University, Wuhan \\ 430072, China
}

\begin{abstract}
Theory construction and data reconstruction are required for the evaluation of quality in China. Taking into consideration existing mature quality evaluation models (particularly the methods of evaluating customer satisfaction) and China's unique national conditions during its economic transition, four dimensions are proposed to evaluate quality in China: consumer satisfaction with quality, product safety, government regulations on quality, and citizen's concept of quality. Based on empirical investigation data in this framework, the overall evaluation of quality in China is summarized as quality in China has just reached a general standard, product safety remains steady as a whole, government quality regulations are ineffective, and Chinese citizens' concept of quality is poor. Correlation analyses show a positive relation between the effectiveness of government regulation on quality and Chinese citizens' concept of quality, consumer satisfaction with quality, and product safety. Finally, the paper proposes the implementation of an emphasis on product safety during quality elevation and quality improvement systems, such as the constant enhancement of quality regulation effects and Chinese citizens' concept of quality, to drive quality development.
\end{abstract}

Keywords: Quality evaluation; Model building; Product safety; Consumers' perception; Survey method

\section{Background}

China is the largest transitional economic body in the world, and the question arises as to whether it has the same attitude towards quality and similar quality standards to developed countries. Theory and experience have both demonstrated that China's economy differs significantly to those of mature market countries across structures and institutions. Hence, there is a substantial difference between the endogenous quality characteristics of its economic system and that of developed countries. The Chinese perception of quality can only be partially interpreted through existing mature quality evaluation systems (such as the macro consumer satisfaction index (CSI) and the performance excellence evaluation method) applicable to developed countries. This paper develops a consumer-based quality evaluation model and uses it to evaluate quality in China, within the framework of China's economic transition situation.

There is a general perception, both nationally and internationally that, overall, product quality is poor in China. Domestically, the outbreak of serious product safety 
incidents such as milk powder and infant formula containing melamine, illegal cooking oil (known as gutter oil, this includes cooking oil reprocessed from waste oil, oil extracted from animal byproducts, and oil collected from drains behind restaurants) and poisonous medical capsules, means consumers are increasingly concerned about product quality. Taking dairy products as an example, although the Chinese government has endeavored to improve the quality of domestic dairy products, the market remains dominated by imported products. There are domestic and international concerns about an overall product safety crisis in China. International media is highly critical of China's product quality and developed countries such as Europe and the USA have raised entry barriers for its products. However, the National Bureau of Statistics of China reveals that the average Chinese lifespan increased by 3.43 years in the 10-year period 2000 to $2010^{\mathrm{a}}$, and that China is now the largest commodity exporter in the world, particularly to countries with strict quality standards such as the US and European countries. Therefore, it can be argued that many evaluations of quality in China are not objective.

There is a considerable gap between China's customer satisfaction evaluation methods (established from the CSIs of developed countries such as the USA) and those of developed countries, because they do not reflect the overall quality situation, or function as an economic barometer like the American Consumer Satisfaction Index (ACSI) does. For example, the recently published Chinese CSI (with a full score of 100) reveals that dairy products score above 70 (including yogurt at 71.17, and liquid milk at 75.49), which is better than that for household chemicals and public services such as education and medical services ${ }^{\mathrm{b}}$. These results show a large discrepancy between the lack of consumer confidence in domestic dairy products and frequent quality problems in dairy product industry in recent years. It indicates the limitations of evaluating quality in China by mature CSI evaluation methods.

In the context of economic transition, quality in China has sophisticated and specific features. Thus, a new evaluation system needs to be established combining China's actual situation during economic transition and existing quality evaluation methods to provide a complete and objective understanding of the current situation of quality in China. Section 'Literature review' of this paper undertakes a literature review where general methods of quality evaluation are summarized and the index system applicable to quality evaluation in China is introduced. Section 'Methods' builds the evaluation model where the quality evaluation framework consistent with China's actual situation is established based on existing literature and in combination with basic features of economic transition. Section 'Investigation, data and key results' provides data and key results by conducting an empirical investigation based on framework analysis to obtain data, and China's overall quality situation is evaluated based on those data. Section 'Correlation analysis' conducts a correlation analysis of the overall characteristics of quality in China. Finally, section 'Conclusions, suggestions, and research prospects' offers conclusions and further research prospects.

\section{Literature review}

Quality evaluation theories and methods have evolved primarily as follows: the constant extension of quality connotations from product quality to fields such as services, projects, and environment and further to the complete and comprehensive economic development quality - in other words, the transition from objective to subjective evaluation. 
First, quality evaluation comes down to the definition of quality. The concept of quality has gone through numerous evolutions; the most authoritative definition to date proposed by the International Organization for Standardization (ISO) is as follows: 'Degree to which a set of inherent characteristics fulfill requirements' (ISO 2000). Hence, inherent characteristics and requirement fulfilling are theoretical foundations for quality evaluation (Juran and Godfrey 2003).

Starting from this definition, Deming (2003) considered 'the quality can only be defined by the degree of customer satisfaction, and the quality is multi-dimensional, so the quality of any product or service cannot be defined by a single feature'. The CSI evaluation system is the primary quality evaluation method. Classic marketing theory and application studies (Kotler 2011) consider that the degree of consumer satisfaction is the consumer's perception of effects or results after comparing similar products. This reflects the gap between the objective attributes of products or services and the consumers' subjective expectation: the size of the gap represents the quality level. Sweden is an example of a country that expresses consumer satisfaction in index and in macroscopic scales. Among its executive CSI barometer indexes, the Swedish Customer Satisfaction Barometer (SCSB) is considered the first truly national satisfaction index, which is classified into five specific indexes: consumer expectations, perceived performance (perceived value), customer complaints, customer loyalty and customer satisfaction, emphasizing the influence of quality expectations and price factors on satisfaction. Based on the SCSB, Fornell et al. (1996) applied a structural equation to construct the ACSI, adding a 'perceived quality' index. They measured customization, reliability and overall evaluation, and expanded the CSI to encompass six indexes including consumer expectations, perceived quality, perceived value, customer complaints, customer loyalty, and customer satisfaction. Their structural equation model is still used as a basis model of quality evaluation; however, its core lies in the comparison between expected value and perceived quality. In considering the factors that determine CSI, Fornell et al. (1996) consider that personalized customization is more influential than reliability; consumer expectation is more influential in industries with low levels of production and consumption; and the CSI is more sensitive to the influence of quality than price. Initiated in 1997, the European Customer Satisfaction Index (ECSI) further developed the ACSI, and used an 'enterprise image' index to replace 'consumer complaint'. Although index evaluation methods vary slightly in different regions and countries because of differences in local economy, culture, and politics, the focus on product performance, service quality and operation quality has no essential differences. Currently, there are several models evaluating CSI, the quadratic graph model, the KANO model, the analytic hierarchy process (AHP) model, and the ACSI model being representative and proving reliable and effective in practice (Anderson et al. 1994).

Methods to evaluate consumer satisfaction are widely applied not only to evaluate product and service quality, but also to evaluate economic development quality to emphasize the gap between objective results and subjective satisfaction (Diener and Suh 1997; Frank and Enkawa 2008; Easterlin and Angelescu 2012). For example, happiness indexes to evaluate life quality in Bhutan include many aspects that evaluate residents' subjective perception. Guangdong Province in China implements 'Happy Guangdong Indexes' include subjective perceptions for various social development aspects such as working conditions and income level satisfaction. The Organization for Economic Co-operation and 
Development (OECD) includes life satisfaction as one of the 11 topics, and it considers essential for material living conditions and quality of life in its 'Your Better Life' index.

China uses the satisfaction method in many theories and practices to evaluate macro quality. In 1990, the quality competent department and the National Statistical Bureau of China jointly formulated the National Industrial Product Quality Index System Overall Plan, a quality index system based on the statistics and analysis of industrial product quality information. Therein, the product quality grade rate reflects the product quality level, the quality loss rate reflects the quality economic index, and the new product output rate and the industrial product sales-output ratio reflect the quality applicability. In 1998, China's Tsinghua University School of Economics and Management was entrusted by the State Bureau of Quality Technical Supervision to carry out the research on 'National Consumer Satisfaction Degree Evaluation Methods'. Its recent Manual of Chinese Consumer Satisfaction Degree in 2012, report includes the scores of consumer satisfaction degree for multiple commodity types ${ }^{\mathrm{b}}$. Furthermore, some local quality inspection departments have investigated the evaluation of macro quality, for example in 2002 Shanghai Municipal Bureau of Quality and Technical Supervision organized the 'Shanghai Consumer Satisfaction Degree and Evaluation Method Research' (Zhang et al. 2002).

Therefore, although quality evaluation theories and methods have changed, the consumer satisfaction degree is an indispensable element of domestic and international quality evaluation methods. However, such evaluation methods cannot comprehensively evaluate overall quality in China because they were proposed and developed in Europe and the USA in the 1990s. In such areas, market development and the government regulatory system are relatively complete, and thus, their primary quality focus is on whether consumers are satisfied rather than safe, specifically, 'the products produced and provided by enterprises bring harms to consumers because of performance defects', (Cheng et al. 2012). For example, the incidence of horsemeat found in beef products during the 2013 European 'Horsemeat scandal' was not a safety issue and was not hazardous to human health. In contrast, many quality incidents in China relate to largescale safety issues. In the 2009 'Sanlu Diary Incident', the harmful agent melamine was added to milk powder, affecting over 1,000 infants and resulting in 6 mortalities. Moreover, there have been incidences of clenbuterol in animal products for human consumption (resulting in food poisoning), and in 2012, substances harmful to human health were added during production of medical gel capsules, generating safety risks. Such examples are known as 'product-safety incidents'. Victims of those incidents have low awareness of safety risks, and may be satisfied with the subjective evaluation of products in terms of the purchase price; however, such products can harm them objectively. Based on internet research, Cheng et al. (2012) found that the printed product safety statement accounted for $85 \%$ of all the quality statements. This shows that even though the existing quality evaluation model is not mentioned or emphasized adequately, it plays a vital role in Chinese consumers' quality evaluation. Therefore, mature market economies such as the USA and Europe can appropriately evaluate the overall quality situation via the consumer satisfaction with quality model, with no systematic bias. However, bias may occur if the consumer satisfaction with quality model is applied to evaluate quality in China.

Based on the analysis of existing literature, the extent of satisfaction is a basic index for evaluation, and the experience in China to date shows that safety evaluation should 
be included in its case. In quality evaluation, product safety is as important an element as consumer satisfaction with quality in developing countries with a low economic development level.

\section{Methods}

\section{Theoretical basis}

\section{Review of existing theories and models}

This paper aims to conduct a quantitative evaluation on China's macro quality and starts by asking if China, as a country in transition, is unique. Our analysis of existing literature revealed that evaluation results would be incorrect if China's macro quality was evaluated by the quality evaluation method dominated by customer satisfaction that is applicable to developed countries. Hence, it is necessary to put forward a new analysis model based on existing evaluation methods and in combination with the macroscopic background of quality development in China (Tao et al. 2013). This model incorporates two aspects: the mature method proposed in the literature review, and the actual background of China's economic transition and its impact on quality development. Two macro-quality evaluation dimensions are attained from existing studies: consumer satisfaction with quality and product safety (Cheng et al. 2011). In consideration of China's particular national situation of economic transition, the content in this framework needs to be supplemented (Weihua and Lijun 2005).

China's economic transition is characterized by the systematic development from a planning to a market system, structural developments from a closed to an opening economy and from an agricultural society to an industrial society. China is undergoing progressive incremental reform that is 'partial, step-by-step and unfinished ${ }^{\prime}$; thus, its economic system combines elements of both the old and new systems. Although China's degree of marketization remains low after over 30 years of market-oriented reform, the liberalization level of the economy is also an important index to evaluate marketization degree (Heritage Foundation 2012). In a 2012 evaluation by the Heritage Foundation, China only scored 50.2 (out of 100) and ranked 138th in the world ${ }^{\mathrm{d}}$. The transition system background decides that government regulation will play a vital role in quality development in China; it also decides that the quality development is different from such developed countries as the USA and Europe. Hence, if the government's role is bypassed when discussing quality there will not be a comprehensive understanding of the internal mechanism of economic development. During economic transition, China's enterprises, governments, and consumers are quite different from those of developed countries. The economist Justin Yifu Lin (2010), in studying China's economic transition, held that industries established in the era of a planning economy, and not qualified for factor endowment comparative advantages, comprised enterprises lacking viability. Thus, during economic transition, the government must adopt the progressive transition of 'making the best use of the circumstances' instead of one-step radical protection. Such progressive reform is considered a successful model. Therefore, during economic transition, many enterprises cannot fully participate in market competition, and thus the government plays a vital role in enterprise development. While this role is considered to be weakening, it cannot be ignored. Therefore, government regulation and relevant institutional design are crucial aspects of quality observation.

Institutions play a key role in economic development. Institutions impose constraints that are 'some restrictions imposed by humans to decide the mutual relations between 
people' (North 1999). It is essential to study the institutional environment in quality research, and the institutional perception of quality decides the behavior of quality. North's constraints include formal rules (such as the common law) and informal restraints (such as custom and behavior criteria). In the field of quality, relevant qualityfocused institutions have decided the performance of quality governance in general. Quality-focused institutions work within formal rules that mainly include government regulations such as laws, regulations, supervision methods, and incentive mechanisms. Informal quality restraints mainly refer to endogenous concepts and quality practices in social culture. This performs a similar function to that of the 'ideology' proposed by North, and plays a vital role in the selection of quality behaviors. The formal constraints and informal restraints of quality are discussed below and their respective roles in quality development are demonstrated.

Statistics reveal that in 2010 in the USA, major federal product safety management departments such as the Food and Drug Administration (FDA) and the Consumer Product Safety Administration (CPSC) were staffed with only 26,727 personnel. This was less than $12.7 \%$ of the 210,000 personnel in China's quality comprehensive management department in the same year, and the percentage would be lower if the personnel in other Chinese quality professional management departments were included. Therefore, the US personnel investment in quality regulation is considerably lower than that of China. As the largest economy and importing country in the world, the USA must regulate, import and export significant numbers of products; hence, it is clear that the USA is more efficient in regulation than China. The key to the above point is the difference between the two regulation institutions. Since the era of 'progressivism' in the early 20th century, the USA has been committed to the ongoing reform of its quality regulatory institutions. The 'three-in-one' modern quality regulatory institution of 'risk driving, independent regulation, and common governance' has now preliminarily come into being (Cheng et al. 2012). A review of the actual situation of quality regulation in China during transition finds that, while regulations on product quality and national product safety have been strengthened, since the 2008 'melamine' milk powder incident, many other incidents, including the 'clenbuterol', 'chrome exceeding standard', and 'poisonous capsule' incidents, have taken place. This indicates that the effectiveness of government regulation is a critical factor restricting the overall development of quality in China.

A further theoretical pillar supporting institutional economics is the ideology theory. Ideology is 'one conservation mechanism through which people can understand the situation and make decisions in a simple and clear manner' (North 1999). It explains why individualism results violate the rule of social moral, culture, and values (informal aspect of institution), while majority results do not. A society that restricts human behavior through formal rules pays a price, while the informal institution can reduce such costs. The quality gap between China and developed countries lies in not only the differences in regulatory institution and methods, but also in the social concept and awareness of quality. In China, not only do enterprises produce and sell counterfeit products, but also the citizens who know they are counterfeit products buy them and even tolerate their existence. Countries with advanced quality levels such as Switzerland, Germany, and Japan have a common societal focus on quality. This is typified by the German quality culture of constant improvement and Japan's 'zero defect' 
quality awareness. Citizens' concept of quality can decide one country or region's quality demand, because citizens who are clearly aware of quality can push the demand for high quality. Specifically, the quality concepts of citizens include the recognition of quality common sense, quality behavior and general daily practices, and the ability to safeguard quality rights. Based on the role of institutions in quality, this paper proposes to strengthen the government regulation on quality and citizens' quality concepts during quality evaluation.

\section{The macro-quality observation model in China}

Briefly, the evaluation of macro quality of countries in transition should include four dimensions: consumer satisfaction with quality evaluation, product safety evaluation, government regulation on quality, and citizen's quality culture. These four aspects constitute the observation model for China's macro-quality evaluation. The theoretical basis for establishing such a model is the institutional economics theory. Quality institution determines the behaviors in quality, and then decides the quality development performance. The logical consideration of a macro-quality observation model is to evaluate the overall quality situation in China, from institution and performance, and to design evaluation indexes based on literature stylized facts and China's transition.

\section{Key concepts}

Some new concepts have been proposed in the framework that need further explanation.

\section{Product safety}

This is sometimes simply referred to as 'safety'. This paper emphasizes quality over product safety (consumer physical and mental injuries from problems in product quality, such as design drawbacks or adding a prohibited ingredient). Product safety is the bottom line of quality that needs to be supervised by the government (Cheng and Li 2009). Consumer perception provides the measurement for this concept.

\section{Quality satisfaction}

This concept is close to CSI, but somewhat different. The concept in this paper focuses on the consumers' direct evaluation of quality (including product, service, public project, and environment), while the CSI is derived by comparing perception and expectation (Cheng 2010). Importantly, in this paper, satisfaction on quality emphasizes that it is a concept relative to product safety, meaning that satisfaction is based on the fact that the product consumed is safe.

\section{Institution environment}

Institutional economist Douglass North first developed the concept of the institution environment. He considered that institutions were the set of rules made by people that regulate people's behaviors. Institutions are of great importance in economic development, verified by theoretical and empirical studies. Quality development is also concerned with the institution environment, defined as government regulations on quality and citizens' quality concept. The institutional environment consists of formal rules such as laws, regulations, and informal constraints such as cultural factors and quality practices.

\section{Consumer perception}

Consumer perception self-reports quality: evaluation is based on a subjective rather than an objective method. This is common in quality evaluation, as the definition of 
quality is "the degree of satisfaction brought by the internal property". Hence, the scores derived in this paper are comprehensive evaluations by consumers after considering the price, comfort, and other factors.

\section{Empirical strategy}

Figure 1 shows the observation model of China's macro quality, based on existing literature and China's national quality development. Two basic model dimensions are the performance of quality development (measured by quality satisfaction and product safety) and the institutional environment of quality development (including formal rules and informal restraints). The specific design focuses on quality satisfaction, product safety, government regulations on quality, and citizen's quality concepts. The specific index design is shown in Table 1.

Based on the framework presented in Table 1, 226 investigation indexes were designed in detail.

\section{Results and discussion}

\section{Investigation structure}

Data were collected by questionnaire and interview, and specific people were selected for interview in several regions nationwide. The total we want to research here is all the consumers that have the ability to evaluate quality. However, it's hard and expensive to cover all the regions. Instead, we choose some of the provinces from the eastern, middle, and western parts, which are classical clarifications of China's economic zones. In each region, several cities are picked as survey units. Together, 48 cities are chosen as survey units. Gallup (an international performance-management consulting company) considers that meeting the quantitative analysis requirements of one problem requires 15-50 effective questionnaires. Quantitative analysis refers to the analysis of the 'quality' of the matter. For the observed object of quality, it means the analysis of 'good' or 'bad' product safety conditions in a region, and the 'high'- or 'low'-quality development level. After the comprehensive consideration of investigation cost and sample effectiveness, the sampling number for investigation in one region was set at 50. To

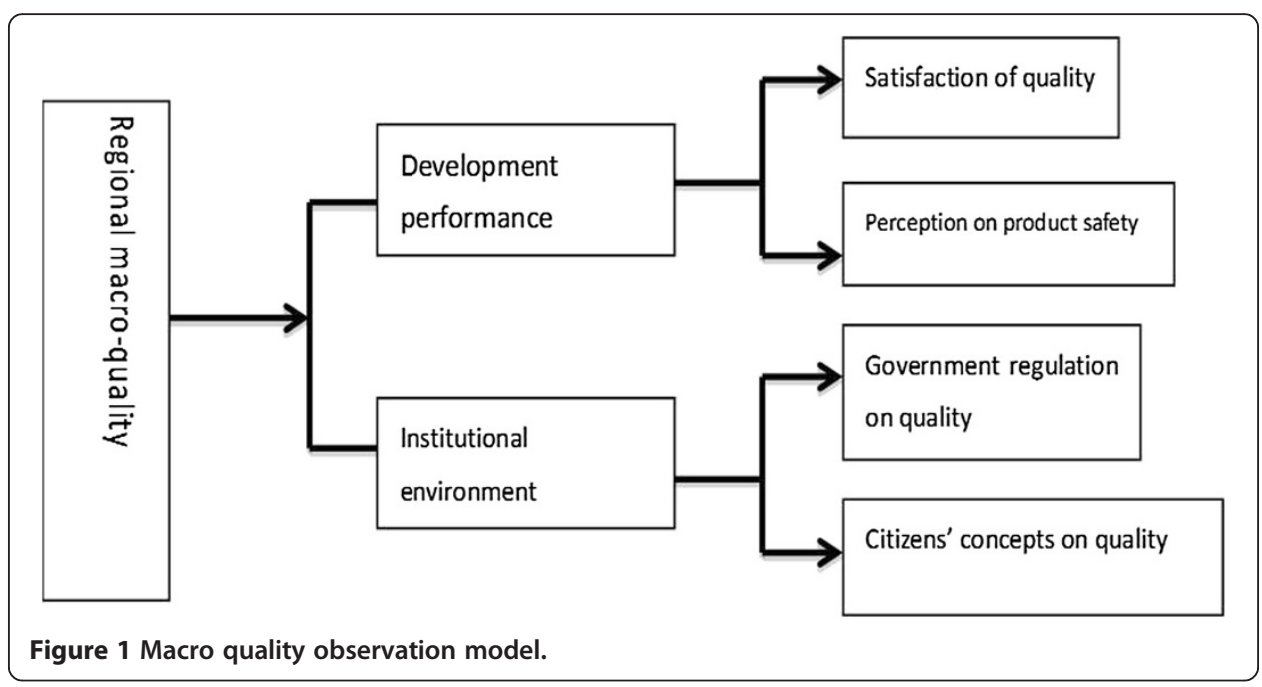


Table 1 Macro quality observation index design

\begin{tabular}{|c|c|c|}
\hline Level I variables & Level II variables & Level III variables \\
\hline \multirow{20}{*}{$\begin{array}{l}\text { Consumer quality } \\
\text { satisfaction }\end{array}$} & \multirow{6}{*}{$\begin{array}{l}\text { Consumer product quality } \\
\text { satisfaction }\end{array}$} & Food \\
\hline & & Medicine \\
\hline & & Daily necessities \\
\hline & & Household appliances \\
\hline & & Automobile \\
\hline & & Means of agricultural production \\
\hline & \multirow{2}{*}{$\begin{array}{l}\text { Consumer construction project } \\
\text { quality satisfaction }\end{array}$} & Building work \\
\hline & & Municipal work \\
\hline & \multirow{4}{*}{$\begin{array}{l}\text { Consumer environment quality } \\
\text { satisfaction }\end{array}$} & Water resources \\
\hline & & Air \\
\hline & & Vegetation \\
\hline & & Noise \\
\hline & \multirow{8}{*}{$\begin{array}{l}\text { Consumer service quality } \\
\text { satisfaction }\end{array}$} & Education service \\
\hline & & Medical service \\
\hline & & Banking service \\
\hline & & Communication service \\
\hline & & Cable television service \\
\hline & & Public transportation \\
\hline & & Real estate service \\
\hline & & Testing service \\
\hline \multirow[t]{7}{*}{$\begin{array}{l}\text { Perception of } \\
\text { product safety }\end{array}$} & \multirow[t]{3}{*}{$\begin{array}{l}\text { Perception of product safety } \\
\text { risks }\end{array}$} & $\begin{array}{l}\text { Perception of the overall situation of product } \\
\text { safety risks }\end{array}$ \\
\hline & & Analysis of reasons for product safety risks \\
\hline & & Perception of product safety risks in specific field \\
\hline & \multirow[t]{2}{*}{$\begin{array}{l}\text { Perception of product safety } \\
\text { incidents }\end{array}$} & $\begin{array}{l}\text { Perception of the occurrence frequency of } \\
\text { product safety incidents }\end{array}$ \\
\hline & & $\begin{array}{l}\text { Perception of the field where product safety } \\
\text { incidents take place }\end{array}$ \\
\hline & \multirow[t]{2}{*}{ Perception of quality defects } & Respondents injured from quality defects \\
\hline & & Other injury from quality defects \\
\hline \multirow{12}{*}{$\begin{array}{l}\text { Quality regulation } \\
\text { and public } \\
\text { services }\end{array}$} & \multirow{5}{*}{$\begin{array}{l}\text { Government regulation on } \\
\text { quality }\end{array}$} & Government quality management position and effect \\
\hline & & $\begin{array}{l}\text { Implementation of quality policies, laws and } \\
\text { regulations }\end{array}$ \\
\hline & & $\begin{array}{l}\text { Establishment of government quality management } \\
\text { department }\end{array}$ \\
\hline & & Government's quality regulation means \\
\hline & & $\begin{array}{l}\text { Institution for government accountability for } \\
\text { product safety incidents }\end{array}$ \\
\hline & \multirow[t]{3}{*}{$\begin{array}{l}\text { Prevention and treatment of } \\
\text { product safety incidents }\end{array}$} & $\begin{array}{l}\text { Government's warnings on and treatments of } \\
\text { product safety risks }\end{array}$ \\
\hline & & Source of governmental product safety information \\
\hline & & $\begin{array}{l}\text { Implementation of compulsory insurance of } \\
\text { high-risk products }\end{array}$ \\
\hline & \multirow{3}{*}{$\begin{array}{l}\text { Government's quality } \\
\text { investment }\end{array}$} & Basic government quality investment \\
\hline & & Field and method of use \\
\hline & & Government quality regulation charges \\
\hline & Quality publicity and education & $\begin{array}{l}\text { Current governmental performance of public } \\
\text { quality education function }\end{array}$ \\
\hline
\end{tabular}


Table 1 Macro quality observation index design (Continued)

\begin{tabular}{|c|c|c|}
\hline & & Access channel and evaluation \\
\hline & & Specific implementation subjects \\
\hline & $\begin{array}{l}\text { Government's quality testing } \\
\text { service }\end{array}$ & $\begin{array}{l}\text { Establishment of government quality testing } \\
\text { institutes }\end{array}$ \\
\hline & & $\begin{array}{l}\text { Evaluation of quality testing institutes affiliated } \\
\text { to the government }\end{array}$ \\
\hline & & Evaluation of quality test service \\
\hline \multirow{9}{*}{$\begin{array}{l}\text { Citizens' quality } \\
\text { concept }\end{array}$} & \multirow{2}{*}{$\begin{array}{l}\text { Consumer quality knowledge } \\
\text { and ability }\end{array}$} & Understanding of product safety knowledge \\
\hline & & Understanding of quality information \\
\hline & \multirow[t]{4}{*}{ Consumers' quality culture } & Opinions on counterfeit and pirate products \\
\hline & & Relation between quality and price \\
\hline & & Relation between quality and brand \\
\hline & & Quality habits during consumption \\
\hline & \multirow{3}{*}{$\begin{array}{l}\text { Consumers' ability and awareness } \\
\text { to safeguard rights }\end{array}$} & Consumers' understanding of safeguarding rights \\
\hline & & Route selection to safeguarding rights \\
\hline & & Cost and effect of safeguarding rights \\
\hline
\end{tabular}

allow for possible ineffective questionnaires, the sample number for the practical investigation was increased to 60 to ensure the number of effective questionnaires per region remained at approximately 50 .

Community personnel (including community workers, retirees and housewives) encounter a variety of quality problems in daily life and have sufficient time to follow commodity quality; hence, they were indispensable for the quality investigation despite being excluded from employment statistics. Experience demonstrates that many quality problems are complained of or reported on by older retirees and housewives.

Therefore, such community representatives could not be ignored, and six quotas were assigned to them. The quota distribution shown in Table 2 was used to determine the corresponding quota and the quota of male and female respondents by the 36 samples

Table 2 Study sample units and quota allocations for urban areas of China

\begin{tabular}{|c|c|c|c|c|c|}
\hline Job type & Units & Sample & Male & Female & Remarks \\
\hline Enterprises in the manufacturing industry & 4 & 12 & 7 & 5 & $\begin{array}{l}\text { Frontline workers and } \\
\text { ordinary managers }\end{array}$ \\
\hline Schools & 2 & 6 & 3 & 3 & $\begin{array}{l}\text { Ordinary teachers on } \\
\text { regular payroll }\end{array}$ \\
\hline Government agencies and social organizations & 2 & 6 & 4 & 2 & $\begin{array}{l}\text { Ordinary staff and middle } \\
\text { managers on regular payroll }\end{array}$ \\
\hline Hospitals and community health stations & 1 & 3 & 1 & 2 & Doctors and nurses \\
\hline $\begin{array}{l}\text { Marketplaces, supermarkets and individually } \\
\text { owned businesses }\end{array}$ & 1 & 2 & 1 & 1 & $\begin{array}{l}\text { Ordinary staff and sole } \\
\text { traders }\end{array}$ \\
\hline Banks, securities, funds, and credit cooperatives & 1 & 2 & 1 & 1 & Middle managers \\
\hline Hotels, ginshops, and restaurants & 1 & 3 & 1 & 2 & $\begin{array}{l}\text { Ordinary staff and middle } \\
\text { managers }\end{array}$ \\
\hline $\begin{array}{l}\text { IT enterprises, research institutes, power supply } \\
\text { and water supply }\end{array}$ & 1 & 2 & 1 & 1 & $\begin{array}{l}\text { Ordinary staff and middle } \\
\text { managers }\end{array}$ \\
\hline Community workers, housewives and retirees & 2 & 6 & 4 & 2 & Aged 18 to 60 \\
\hline In total & & 42 & 23 & 19 & \\
\hline
\end{tabular}


allocated to urban investigation based on the relative ratio of employment in various industries in Table 3. Certain restrictions were imposed on respondents' identity and position in different units to make respondents more representative.

A number of units (industries, organizations, sectors, representatives) were identified for the 42 samples chosen for urban investigation. Generally speaking, three targets were investigated in each unit, and in some cases, two units were sampled in industries with a large number of employers and significant internal differences. During the target sampling within each chosen unit, age (elder, middle, and young), and income (low, middle, and high) were considered. Thus, 42 urban respondents were determined, approximately $70 \%$ of the sampling population of 60 persons. One enterprise and three individual industrialists were sampled in the wholesale and retail industries. In the manufacturing industry, a state-owned enterprise, and a private enterprise were chosen. Two communities were selected. An urban sample size of 42 is shown in Table 2. In conclusion, in the determination of the specific sample, the universality and representativeness of the sample distribution should be fully considered, and it should be representative for several dimensions to avoid the selection bias of systematic samples. Specific sampling units and quota allocation are shown in Table 2.

In the study's rural investigation, one town was selected based on stratified sampling, and three villages were chosen based on random sampling of the income system. Six to

Table 3 Study questionnaire distribution by area

\begin{tabular}{|c|c|c|c|c|c|}
\hline Province & City & Sample size & Province & City & Sample size \\
\hline Beijing & - & 59 & Jiangxi & Leping & 60 \\
\hline \multirow[t]{2}{*}{ Tianjin } & - & 60 & Shandong & Laiwu & 59 \\
\hline & - & 60 & Henan & Pingdingshan & 56 \\
\hline \multirow[t]{3}{*}{ Hebei } & Shijiangzhuang & 60 & & Ruzhou & 58 \\
\hline & Zaoqiang & 58 & & Zhengzhou & 60 \\
\hline & Weixian & 60 & & Xinxiang & 60 \\
\hline \multirow[t]{2}{*}{ Shanxi } & Xiangfen & 56 & & Xuchang & 60 \\
\hline & Xinzhou & 44 & Hubei & Wuhan & 60 \\
\hline Liaoning & Dalian & 50 & & Lichuan & 59 \\
\hline Jiling & Meihekou & 60 & & Gong'an & 56 \\
\hline Shanghai & Shanghai & 60 & & Nanzhang & 50 \\
\hline \multirow[t]{2}{*}{ Jiangsu } & Wuxi & 50 & Hunan & Yueyang & 60 \\
\hline & Jurong & 50 & & Yongzhou & 60 \\
\hline \multirow[t]{3}{*}{ Zhejiang } & Haining & 56 & Guangdong & Shantou & 55 \\
\hline & Jiande & 58 & & Foshan & 58 \\
\hline & Shaoxing & 60 & Guangxi & Nanning & 60 \\
\hline \multirow[t]{3}{*}{ Anhui } & Anqing & 60 & Hainan & Sanya & 53 \\
\hline & Wuhu & 49 & & Wanning & 60 \\
\hline & Bozhou & 59 & Chongqing & Dianjiang & 56 \\
\hline \multirow[t]{2}{*}{ Fujian } & Yongtai & 49 & & Zhongxian & 60 \\
\hline & Jinjiang & 40 & Guizhou & Kaili & 60 \\
\hline \multirow[t]{3}{*}{ Xinjiang } & Urumchi & 61 & Shanxi & Sanyuan & 60 \\
\hline & Korla & 55 & Ningxia & Yinchuan & 60 \\
\hline & Kashgar & 48 & Sichuan & Suining & 60 \\
\hline
\end{tabular}


eight respondents were selected in each village; thus, the total size of rural sampling was approximately 20 . In each village, two to three respondents were selected in the relevant income groups (low, middle, and high).

In consideration of the significant differences in urban and rural development in various regions, more rural samples were given in less urbanized regions. As the current urban population in China is approximately $50 \%$, certain adjustments were made to the quota allocation of the urban-rural sample, shown in Table 4.

\section{Data description}

\section{Statistical population and distribution}

During the study, 3,736 questionnaires were distributed; of these, 3,416 were returned. After questionnaire screening, 2,865 questionnaires were considered effective, thus the return rate of effective questionnaires was $76.7 \%$.

Questionnaires were distributed in 48 regions in 26 provinces including Beijing, Tianjin, Hebei, Shanxi, Inner Mongolia, Liaoning, Jilin, Shanghai, Jiangsu, Zhejiang, Anhui, Guangdong, Guangxi, Chongqing, and Hainan, covering $81.25 \%$ of all provincial administrative units in Mainland China. Specific regions are shown in Table 3.

\section{Analysis of sample frame}

Table 5 shows the gender, age, ethnicity, type of registered permanent residence, marital status, educational background, nature of work unit, job position, family structure, number of children in family, and monthly family income of the samples.

The sample statistics show that all samples in this study included different dimensions, with no extreme concentration at either end of the dimension's spectrum; thus, it is well representative in general.

\section{Descriptive statistic analysis}

The quality observation model proved that safety is the most important aspect for quality in transitional countries. This study revealed that the majority of Chinese consumers (60.88\%) feel 'neither good nor bad' about product safety, (i.e. better than 'bad' but worse than 'good'). Those feeling 'good' account for $22.68 \%$, about 10 percentage points more than for those feeling 'bad' (12.93\%), and those feeling 'very good' account for $2.2 \%$, about one percentage point higher than for those feeling 'very bad' (1.31\%) (Figure 2). This indicates that in general Chinese consumers' perception of product safety is normal. That is, most of the consumers do not feel unsafe about quality although not satisfactory. However, it is still $27.32 \%$ lower than the percentage of 'good' product safety.

Of the ten investigated factors, consumers considered food (88.27\%) and medicine (77.05\%) to have the highest safety risks (Figure 3). The perceived risks of food and medicine are higher than those of the third highest ranked factor, daily necessities, by 50.91 and 39.69 percentage points, respectively, and are higher than those of the lowest ranked factor, agricultural means of production, by 76.28 and 65.06 percentage points,

\section{Table 4 Study allocation of urban samples, China}

\begin{tabular}{lcc}
\hline Percentage of urban population & Urban samples & Rural samples \\
\hline$\leq 50 \%$ & 36 & 24 \\
$>50 \%$ & 42 & 18 \\
\hline
\end{tabular}


Table 5 Sample frame

\begin{tabular}{|c|c|c|}
\hline Type & Option & Percentage (\%) \\
\hline \multirow[t]{3}{*}{ Gender } & Percentage of males & 51.08 \\
\hline & Percentage of females & 48.92 \\
\hline & Total & 100 \\
\hline \multirow[t]{5}{*}{ Age (years) } & 18 to 35 & 47.71 \\
\hline & 36 to 50 & 39.72 \\
\hline & 51 to 54 & 5.86 \\
\hline & 55 to 60 & 6.71 \\
\hline & Total & 100 \\
\hline \multirow[t]{3}{*}{ Ethnicity } & Han Ethnicity & 90.85 \\
\hline & Minority & 9.15 \\
\hline & Total & 100 \\
\hline \multirow[t]{3}{*}{ Registered permanent residence } & Permanent urban residence & 66.63 \\
\hline & Permanent rural residence & 33.37 \\
\hline & Total & 100 \\
\hline \multirow[t]{3}{*}{ Marital status } & Married & 73.23 \\
\hline & Unmarried & 26.77 \\
\hline & Total & 100 \\
\hline \multirow[t]{6}{*}{ Education level } & Below senior middle school & 20.34 \\
\hline & Senior middle school/technical secondary school & 23.87 \\
\hline & Junior college & 23.94 \\
\hline & Undergraduate & 29.60 \\
\hline & Postgraduate & 2.25 \\
\hline & Total & 100 \\
\hline \multirow[t]{7}{*}{ Nature of work unit } & Government agencies & 10.09 \\
\hline & Public institutions & 24.19 \\
\hline & State-owned enterprises & 13.51 \\
\hline & Private enterprises & 23.66 \\
\hline & Foreign-funded enterprises or joint ventures & 2.37 \\
\hline & Miscellaneous & 26.18 \\
\hline & Total & 100 \\
\hline \multirow[t]{6}{*}{ Job position } & Intermediate and senior managerial staff & 6.52 \\
\hline & Ordinary managerial staff & 20.38 \\
\hline & Ordinary staff & 48.90 \\
\hline & Agricultural workers & 9.81 \\
\hline & Miscellaneous & 14.39 \\
\hline & Total & 100 \\
\hline \multirow[t]{6}{*}{ Monthly family income } & Minimum living standard & 1.85 \\
\hline & Below RMB 3,000 & 35.11 \\
\hline & RMB 3,001 to 5,000 & 37.09 \\
\hline & RMB 5,001 to 10,000 & 18.30 \\
\hline & Over RMB to 10,000 & 7.65 \\
\hline & Total & 100 \\
\hline
\end{tabular}




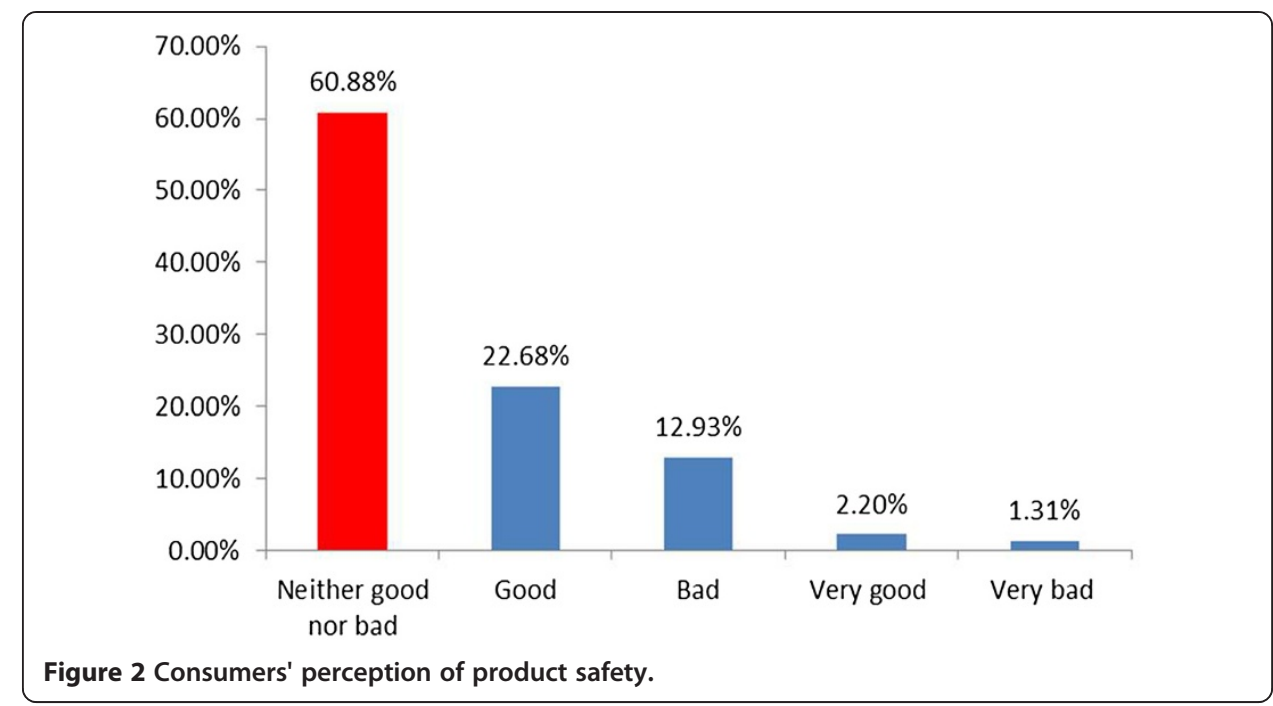

respectively. This reveals that in a country with poor economic development, safety risks relating to basic consumption goods represented by food and medicine are the highest.

The authors consider that China's product quality is greatly criticized; however, the investigation results demonstrated that satisfaction score (with full score 100) on product quality was the highest, and the environment was the lowest. These results show that China, as the largest manufacturing country in the world, has witnessed an accelerated improvement of product quality. Hence, product quality enjoys higher satisfaction levels than service quality, construction project quality and, particularly, environment quality. Dissatisfaction with environment quality indicates consumer emphasis on environment quality after the basic demand for product quality is widely satisfied. However, while product quality ranks first in satisfaction, it only scores 64.72 , over 5 points lower than the level of 'satisfaction'. A comprehensive consideration of the four fields reveals that the average quality satisfaction is 62.02, showing that quality development in China has reached the 'standard' level (which means almost satisfactory in traditional Chinese perception), but is

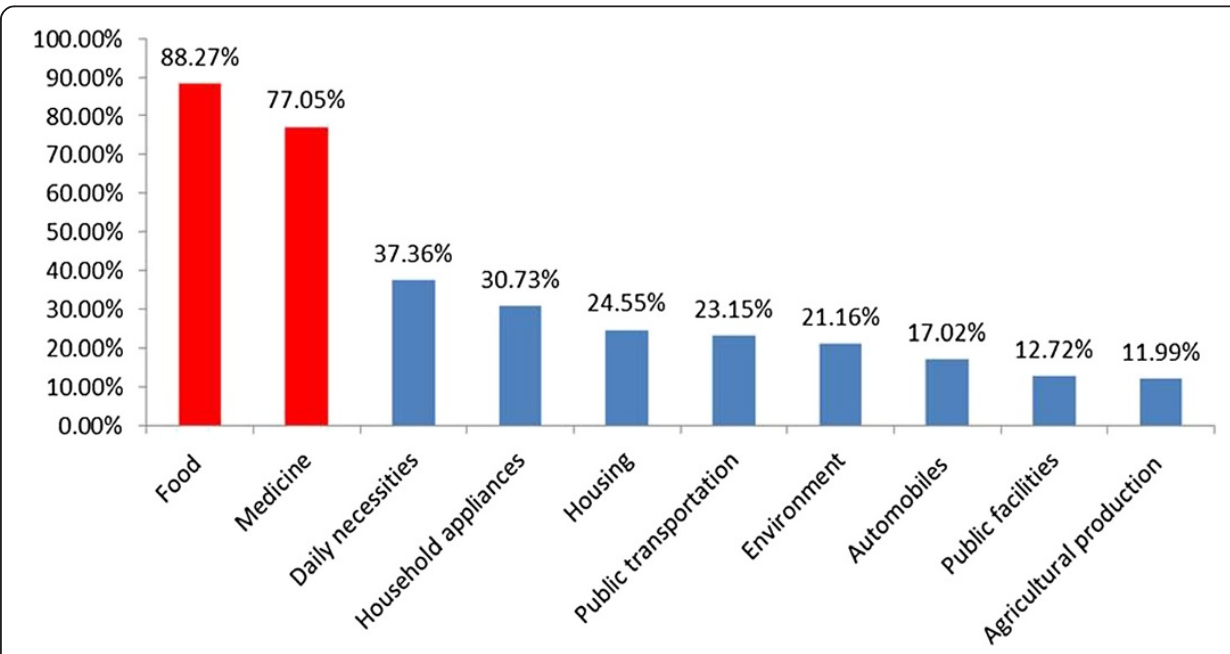

Figure 3 Rank of risk perception of product safety for various factors. 
still far from the satisfactory level (which has to reach a score of 80 ). This score basically reflected the current situation of quality development in China (Figure 4).

When evaluating the existing government's quality management effect, $46.87 \%$ of consumers rate it between 'unsatisfactory' and 'effective'. It is considered 'unsatisfactory' by $32.37 \%$. This is 24.17 percentage points above those rating it 'effective', indicating that government quality management has a long distance to go to reach the 'effective' level (Figure 5). Against the institutional background that China's overall quality development is still at an early stage, the effectiveness of quality regulation in China needs to be further enhanced. Li (2013) has investigated this problem for more detail.

Over $80 \%$ of the consumers buy counterfeit products (Figure 6). This illustrates that not only do Chinese enterprises a have weak sense of responsibility, releasing many counterfeit products to the market, but also that ordinary consumers tolerate counterfeit products and are willing to buy them at a lower price than that charged for genuine products. This reveals that China's development is faced with both consumer low quality 'soft power' and weak fundamental quality institutions.

\section{Correlation analysis}

China is a large country with considerable internal variations, and different regions have different characteristics in the quality development levels and structures. A correlation analysis was undertaken on sample data from 48 regions on the quality institution and quality performance, and their relation was clarified. Four groups of relations are validated in this section, encompassing the correlation between any two aspects: quality satisfaction, product safety, government regulations on quality, and Chinese citizens' concept of quality. The effect of government regulation on quality is measured by 'good' or 'very good' percentages. Citizens' concepts of quality are measured by 'the percentage of those willing to report counterfeit products'. Quality satisfaction is measured by product quality satisfaction and service quality satisfaction scores.

The correlation analysis, however, does not intend to support the framework presented in section 'Methods' on a quantitative basis, as the number of surveyed areas is 48. The aim of this section is to obtain information on the relationship between quality performance and quality institutions on a qualitative basis to verify whether the two

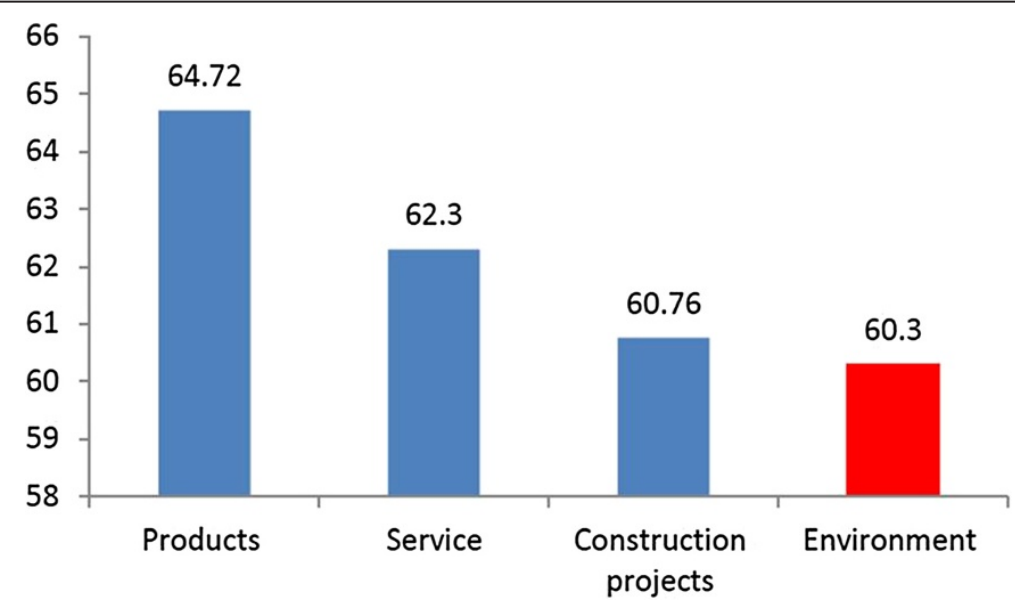

Figure 4 Consumer satisfaction scores on quality for four fields. 


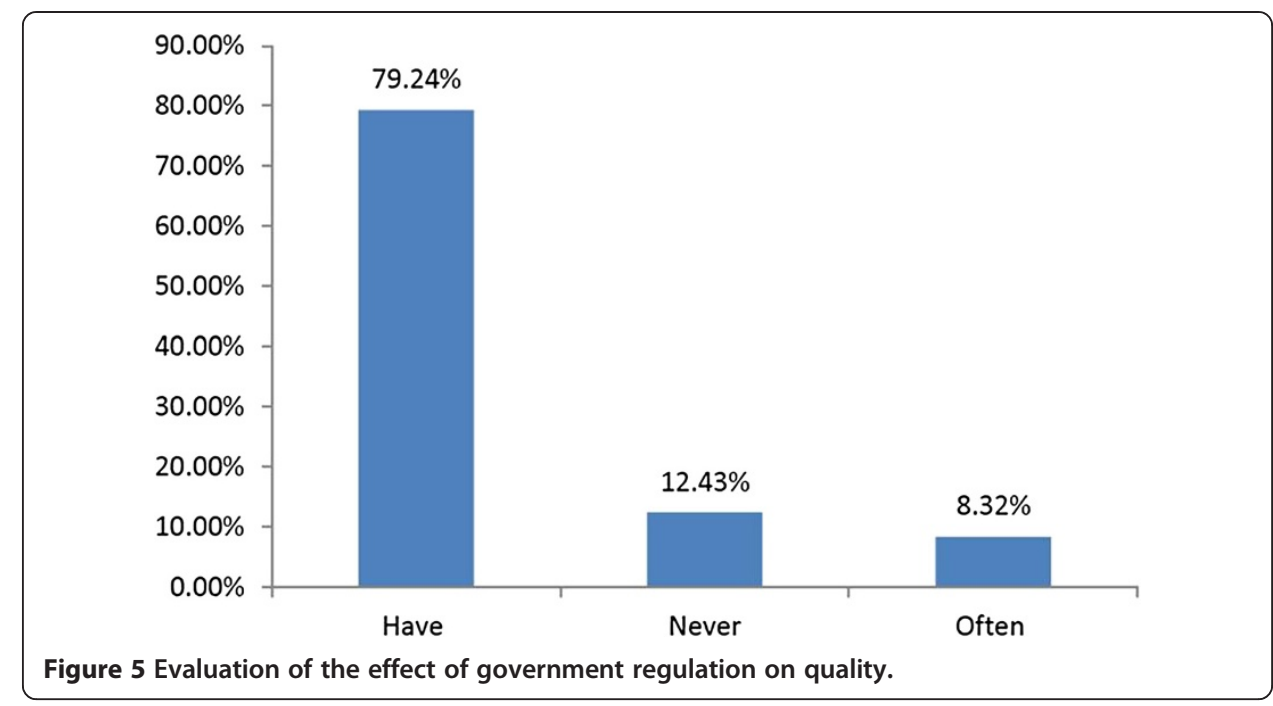

aspects are correlated. Quantitative analysis will be carried out in 2013 with more samples and quantitated variables.

In Table 6, the product quality and service quality refer to the quality development performance, and the other two parts including regulation effects and consumers' reports on counterfeit products represent quality development institution, as discussed in section 'Methods'. Overall, quality performance (represented by satisfaction in product, service, and product safety) is significantly positively correlated with quality institution, although the causality between the two aspects is unclear.

\section{Quality satisfaction extent and the effect of government regulation on quality}

Figures 7 and 8 show that regardless of satisfaction relating to product quality and service quality, both are in positive correlation with the effect of government regulation on quality in general (the straight lines in the figures are linear curve fitting with a

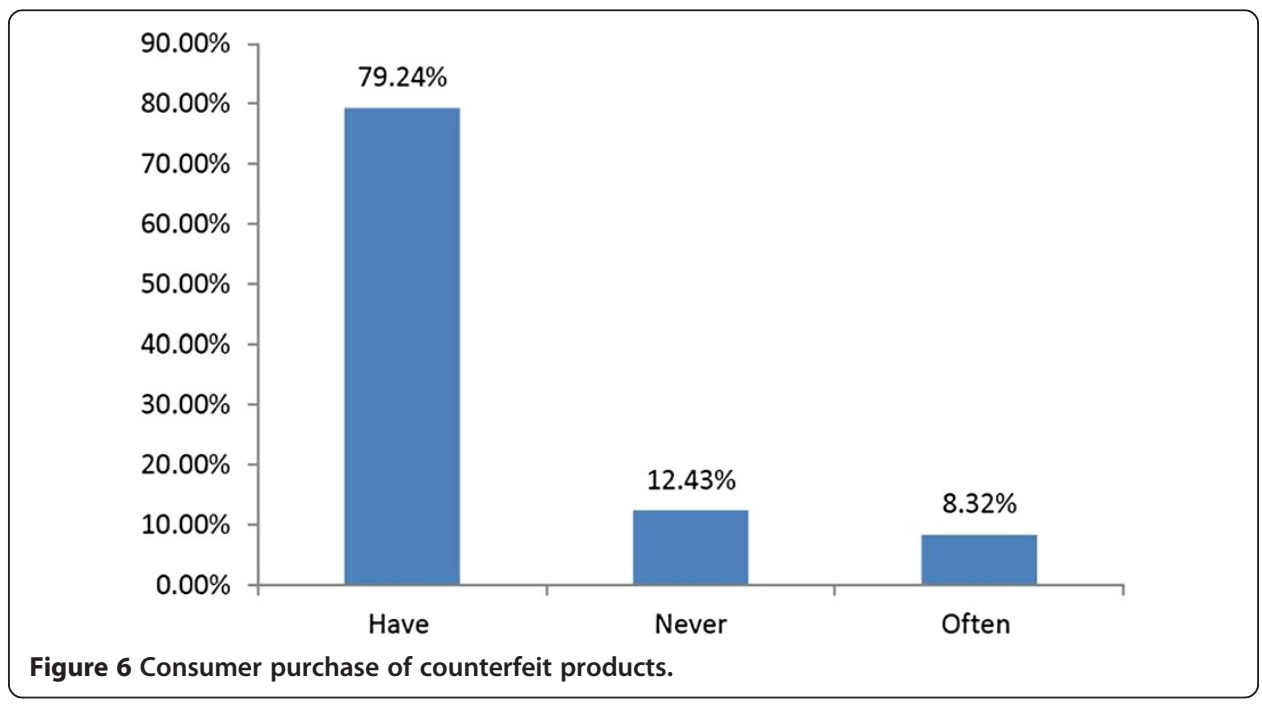


Table 6 Correlation coefficients between quality performance and quality institution

\begin{tabular}{lccccc}
\hline & $\begin{array}{c}\text { Product } \\
\text { quality }\end{array}$ & $\begin{array}{c}\text { Service } \\
\text { quality }\end{array}$ & $\begin{array}{c}\text { Product } \\
\text { safety }\end{array}$ & $\begin{array}{c}\text { Regulation } \\
\text { effect }\end{array}$ & $\begin{array}{c}\text { Consumers' } \\
\text { reports }\end{array}$ \\
\hline Product quality & 1 & - & - & - & - \\
Service quality & 0.645 & 1 & - & - & - \\
Product safety & 0.653 & 0.530 & 1 & - & - \\
Regulation effect & 0.417 & 0.460 & 0.562 & 1 & - \\
Consumers' reports & 0.249 & 0.249 & 0.240 & 0.519 & 1 \\
\hline
\end{tabular}

positive slope), with coefficients of 0.417 for product quality and 0.460 for service quality. Hence, empirical data show that as a formal institution, the design and performance of the government's quality regulatory rules produce a positive impact on quality satisfaction; and the satisfaction degree of product and service quality are generally higher in regions with satisfactory regulation effects.

\section{Quality satisfaction extent and citizens' concepts of quality}

Figures 9 and 10 show obvious positive correlations between the satisfaction degree of product quality and citizens' concepts of quality (the ratio of reported counterfeit products). The result is the same for service quality, with both correlation coefficients being 0.249.

\section{Product safety, government regulation on quality, and citizens' concepts of quality}

The coefficient between product safety evaluation and government regulation is 0.562 , which is the highest of all six coefficients. This both reflects that the Chinese emphasize safety when considering quality and that the government has considerable responsibility in making people safe.

Figures 11 and 12 show a clear positive correlation between the product safety perception (higher percentage), the effect of government regulation on quality, and citizen's quality concepts, particularly the positive correlation between product safety perception and

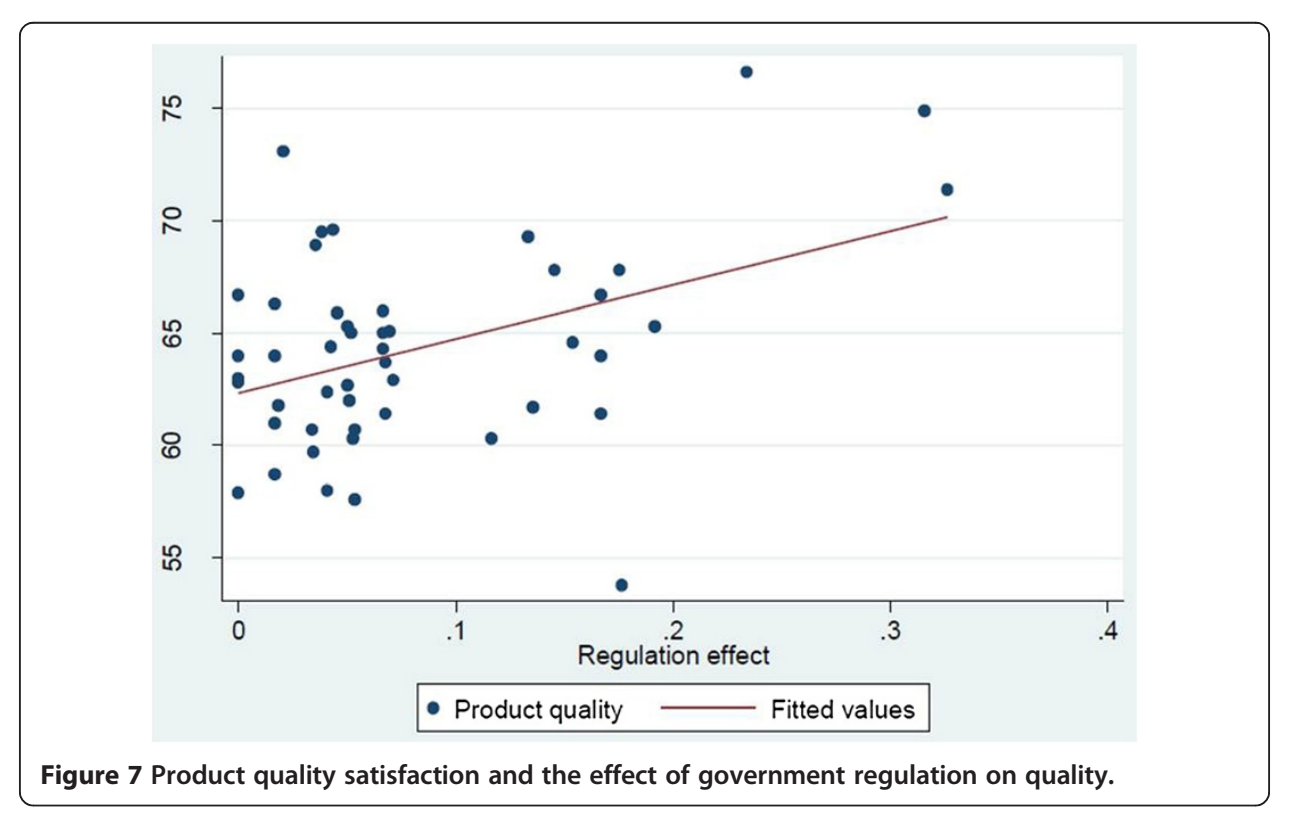




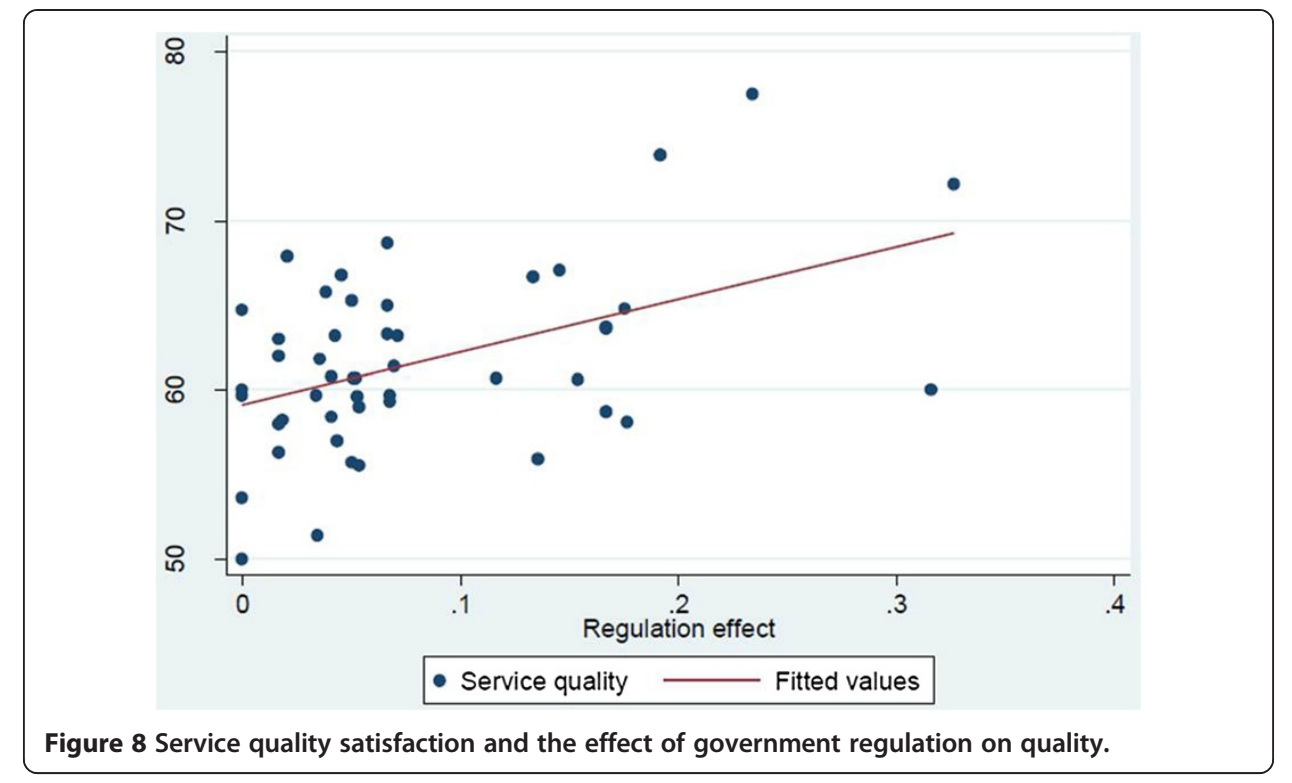

the effect of government regulation. The improved effect of government regulation on quality can significantly enhance the product safety perception. This further illustrates that Chinese consumers' product safety perception is significantly related to government regulation. Hence, government should focus on guaranteeing product safety.

These empirical analysis results preliminarily validate the theoretical assumption herein, namely an obvious correlation between quality institutional design and institution performance. Moreover, it shows that this is a positive correlation, and quality institution plays a decisive role in quality performance. This analysis emphasizes the need to be aware that in a country in transition at an early stage of quality development, such as China, product safety is more sensitive toward quality institution (especially

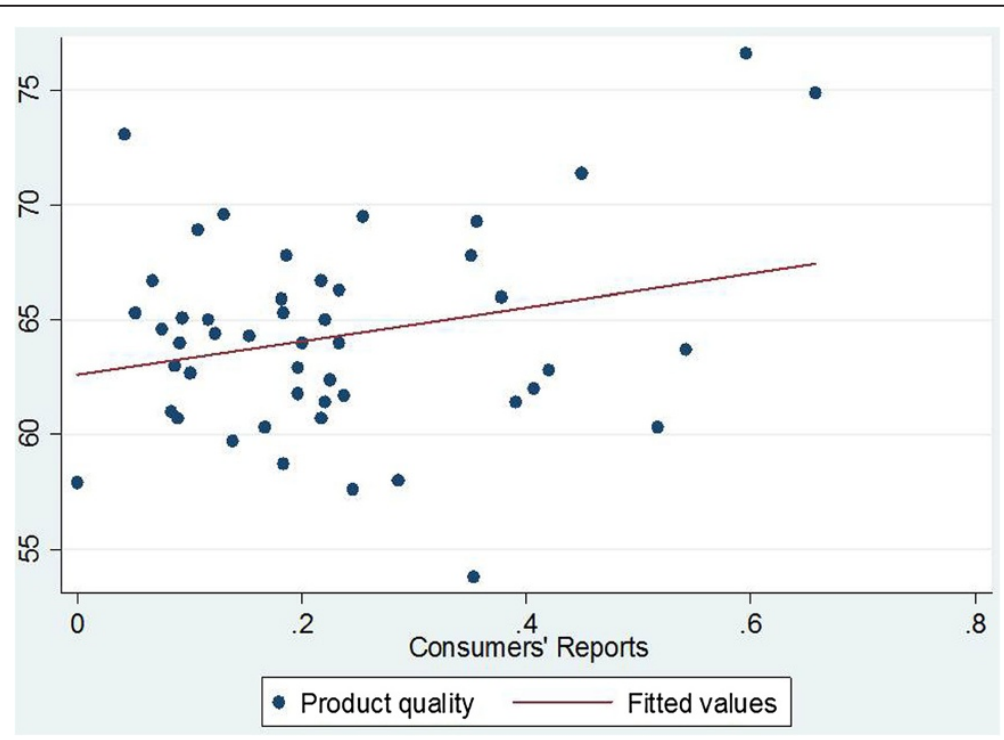

Figure 9 Ratio of satisfaction of product quality to reported counterfeit products. 


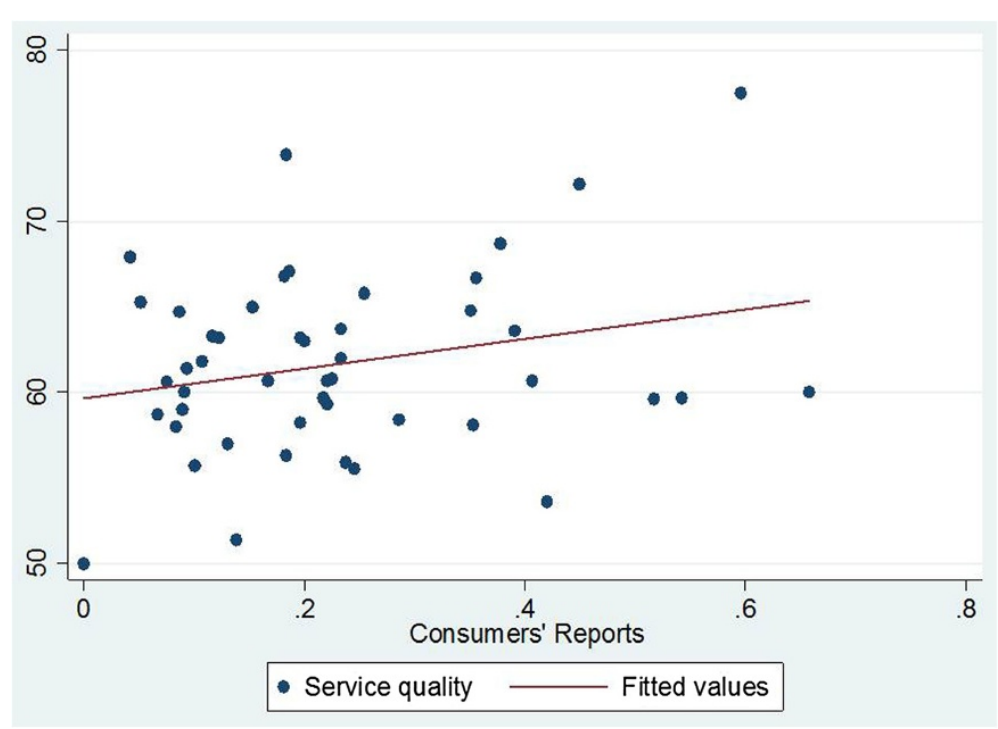

Figure 10 Ratio of satisfaction of service quality to reported counterfeit products.

formal institution), and it is essential to reform the government's regulatory institution to improve its effectiveness and further enhance product safety perception.

\section{Conclusions, suggestions, and research prospects}

An evaluation model of overall quality in China is proposed from the perspective of consumers' perception. Two analysis dimensions are summarized based on the study and analysis of existing literature: consumer satisfaction with quality and product safety. Two new evaluation dimensions are proposed from the comparative analysis between China's specific economic transition background and developed countries'

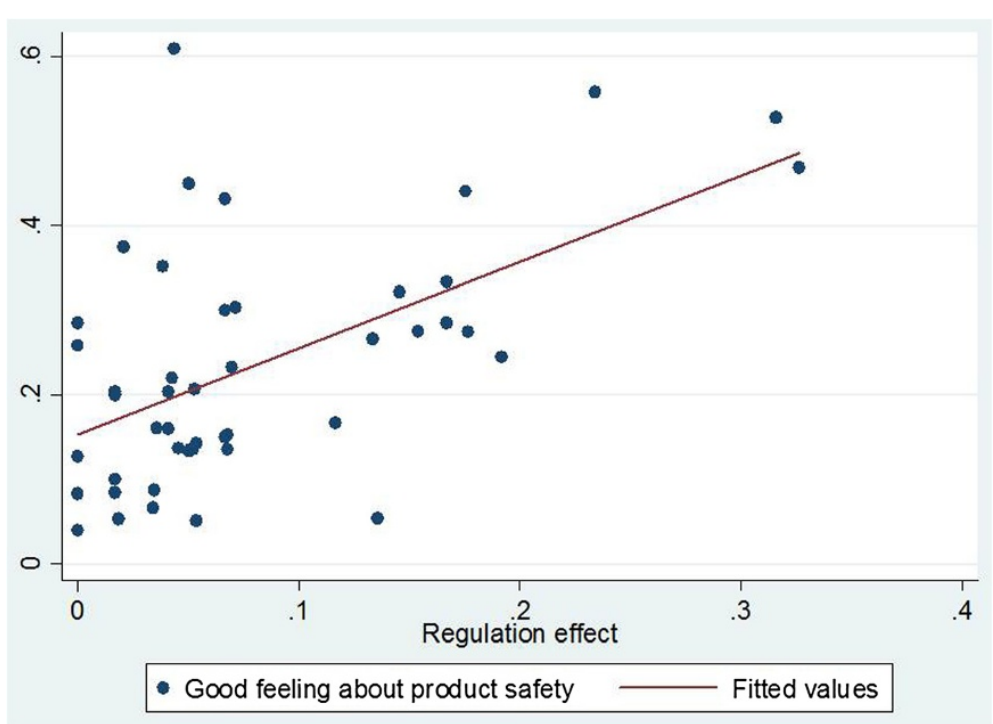

Figure 11 Product safety perception and the effect of quality regulation. 


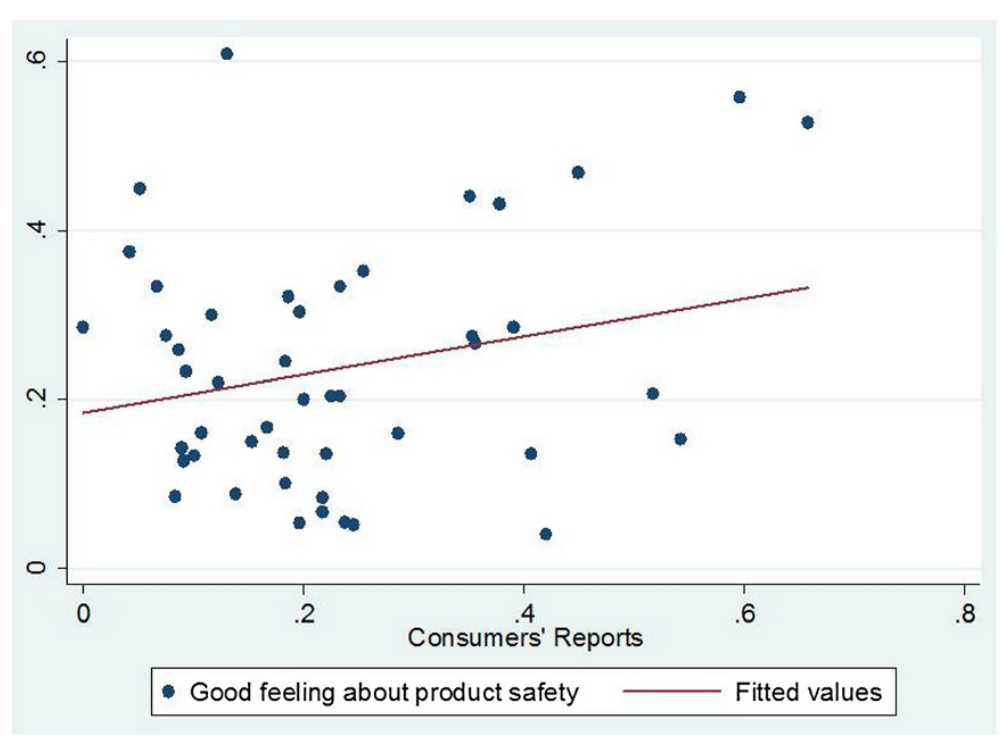

Figure 12 Ratio of product safety perception to reported counterfeit products.

quality development: the effect of government regulation on quality and citizens' concepts on quality. With the application of institutional economics theories, these four dimensions are classified into quality performance (consumer satisfaction with quality and product safety) and quality institution (government regulation on quality and citizen's quality concepts). The analysis of investigation data has verified the positive correlation between performance and institutional environment of China's current quality development on a qualitative basis, and institutional restrictions on enhancing consumer satisfaction with quality and product safety perception. Based on the above analysis, several policy suggestions are proposed.

First, in overall quality evaluation, product safety should be emphasized. This paper found that product safety is seldom involved in existing mature quality evaluation models; thus, evaluating China's current quality situation using this method would produce defective results. Because China is a developing country, product safety (indispensable in overall quality evaluation) remains a prominent problem. Survey data show that the quality performance measured by quality satisfaction and product safety is above the qualifying score of 60 . Chinese people care most about safety relating to medicine and food. Although having a score of over 60 in the overall quality level, Chinese consumers are not particularly satisfied with the government in relation to quality, such as quality supervision and public services.

Second, the level of quality development should be further enhanced by improving the institutional environment of quality development. Empirical investigation data in this paper show that China's consumer satisfaction with quality and product safety has just reached the standard. With the improvement in living standards, there will be a higher demand for quality. The analysis revealed that an important restraint to quality development in China is the poor institutional environment (Cheng 2013). This manifests as formal rules such as government regulation on quality, and informal constraints such as citizens' concepts of quality (Luo 2013). The constant improvement of regulatory patterns and the enhancement of social quality concepts are the foundation for quality improvement. 
Third, there is a need to strengthen the construction of macro-quality observation and investigation foundations. The premise of and the basis for the scientific quality decision making is the correct understanding of the national quality situation. However, the analysis herein shows that most existing quality evaluation methods only borrow developed countries' models mechanically, seldom take China's special characteristics during its economic transition into consideration, and lack the essential data construction for a general understanding of quality in China. Therefore, it is necessary to build a quality observation model from the perspective of China's national situation of economic transition, and strengthen the data construction based on consumer research.

Finally, it should be noted that this paper should be further improved in two aspects. A four-dimensional aggregate index should be established to obtain the importance degree of the four different dimensions. This paper proposes a new analysis model for quality evaluation in China, but does not investigate how to aggregate different dimensions and obtain the total index of quality development for study. By obtaining this index, the model would be more applicable, and the quality development between countries and between regions could be compared. Furthermore, the weak points of quality development in one country or region could be found. It is necessary to conduct a more in-depth analysis of the institutional environment of quality development. The institution is complex in nature; thus, it is necessary to design a scientific index to measure problems existing in the institutional environment of quality development to propose specific policies and suggestions on perfecting institutional construction.

\section{Endnotes}

a Sources: China Statistical Yearbook 2000 and China Statistical Yearbook 2010.

bSources: http://www.ccsi.org.cn/xwdt/201204/t20120427_12178.html.

'These results are cited from: Loren Brandt, Thomas G. Rawski (eds) (2008) China's Great Economic Transformation. Bejing: Truth and Wisdom Press, pp.16.

${ }^{\mathrm{d}}$ The data is cited from the official website of Heritage Foundation: http://www.heritage. org/index/country/china.

${ }^{\mathrm{e}}$ Data come from: Cheng et al. (2012). Research on quality management institution of the United States government and its implications, China Soft Science, 12:1-15.

Competing interests

The authors declare that they have no competing interests.

\section{Authors' contributions}

$\mathrm{HC}$ designed the analyzing framework and completed the section on the Chinese quality observation model construction. DL contributed to the empirical method design and completed the section on data description. LL participated in the theories review, the data analysis, the background, and the overall connection of the five parts.

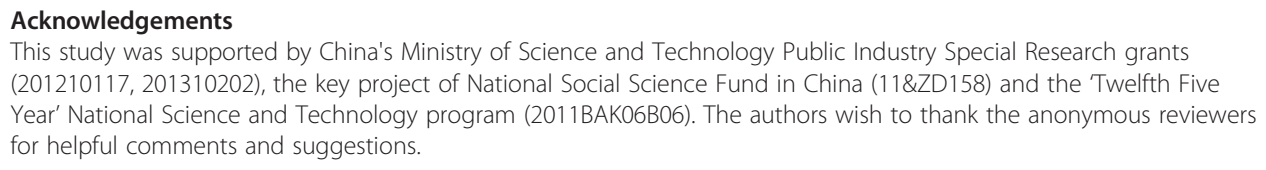


Cheng H (2013) The general situation of China's quality in 2012: consumer perception and model construction. J Macro-quality Res 1:33-48

Cheng H, Fan H, Luo Y (2012) Research on quality management institution of the United States government and its implications. China Soft Science 12:1-15

Cheng H, Li D, Fan H (2011) Macro-quality statistics and analysis. Peking University Press, Beijing

Cheng H, Li Q (2009) National regional overall quality index model system and evaluation Research. Management World 001:2-9

Deming WE (2003) Deming on quality management. Hainan Press, Hainan

Diener E, Suh E (1997) Measuring quality of life: economic, social, and subjective indexes. Soc Indexes Res 40(1-2):189-216

Easterlin RA, Angelescu L (2012) Modern economic growth and quality of life: cross-Sectional and time series evidence. In: Land KC (ed) Handbook of social indicators and quality-of-life research. Springer, New York and London

Fornell C, Johnson M, Anderson E, Cha J, Bryant B (1996) The American customer satisfaction index: nature, purpose, and findings. The Journal of Marketing 60:7-18

Frank B, Enkawa T (2008) How economic growth affects customer satisfaction. Asia Pacific Manage Rev 13(2):531-544

Heritage Foundation (2012). http://www.heritage.org/index/country/china. Accessed 25 May, 2013

ISO (2000) ISO 9000: 2000. http://wiki.mbalib.com/wiki/IS09000\%EF\%BC\%9A2000. Accessed on 30 April, 2013

Juran JM, Godfrey BA (2003) Juran Quality Manual. China Renmin University Press, Beijing

Kotler P (2011) Marketing management. Prentice Hall, New Jersey

Li D (2013) Study on the influence factors of government quality regulatory customer satisfaction index.

J Macro-quality Res 1:76-88

Lin Yifu J (2010) New structural economics: reconstructing the framework of development economics. China Econ Quarterly 1(10):1-32

Luo L (2013) Does urban-rural duality of quality exist in China. J Macro-quality Res 1:107-117

North D (1999) Institutions, institutional change and economic performance. Business Express, Beijing

Tao Y, Changyu L, Gaoshan W (2013) Influencing factor evaluation of regional product quality based on factor analysis. Dongyue Tribune 2:101-205

Weihua F, Lijun W (2005) National quality evaluation issues and institutional construction. Chinese Public Administration 7:35-38

Zhang X, Peng T, Lieping Z (2002) Research on the CSI evaluation model of Shanghai. Ind Engineering Manag 5:29-33

doi:10.1186/s40527-014-0003-7

Cite this article as: Cheng et al:: The Chinese perception of quality: model building and analysis based on consumers' perception. Journal of Chinese Management 2014 1:3.

\section{Submit your manuscript to a SpringerOpen ${ }^{\circ}$} journal and benefit from:

- Convenient online submission

- Rigorous peer review

- Immediate publication on acceptance

- Open access: articles freely available online

- High visibility within the field

- Retaining the copyright to your article

Submit your next manuscript at $\boldsymbol{\sim}$ springeropen.com 